\title{
ANTERIOR CRUCIATE LIGAMENT RECONSTRUCTION WITH FRESH-FROZEN PATELLAR TENDON ALLOGRAFTS
}

\author{
J. R. Valenti, D. Sala, and D. Schweitzer
}

Department of Orthopaedic Surgery and Traumatology, University Clinic, School of Medicine, University of Navarra, Pamplona, Spain

Reprint requests to: J. A. Valenti,
Departamento Cirugía
Clínica Universitaria, Apto 192, E-31080
Pamplona, Spain

\section{SUMMARY}

A prospective study was performed on 30 patients who underwent an anterior cruciate ligament reconstruction with fresh-frozen patellar tendon allograft. An arthroscopic technique alone was used in 10 patients, and in the other 20 patients this was combined with a miniarthrotomy. After a mean follow up of 35 months, the overall functional results were satisfactory in $85 \%$. There were no cases of infection, disease transmission or tissue rejection. Fresh-frozen patellar tendon allografts are a good method of anterior cruciate reconstruction.

\section{RÉSUMÉ}

On a réalisé une étude prospective sur 30 patients traités, de 1988 à 1991, par reconstruction du ligament croisé antérieur (LCA) à l'aide d'allogreffes congelées fraîches de tendon rotulien (os-tendon-os). L'intervention, avec forage d'un tunnel fémoral et tibial, a été pratiquée sous simple arthroscopie dans 10 cas, tandis que chez les 20 autres patients elle a été associée a une mini-arthrotomie. Les opérés ont été suivis 35 mois en moyenne, avec un résultat fonctionnel global satisfaisant dans $85 \%$ des cas. Pour cette évaluation on a utilisé la cotation ARPEGE. On n'a observé aucun cas d'infection, de transmission de maladie ou de rejet immunologique. En conséquence nous pensons que les allogreffes congelées fraîches de tendon rotulien représentent une alternative valable dans le traitement des lésions du LCA. 


\section{INTRODUCTION}

The treatment of anterior cruciate ligament (ACL) lesions is still controversial [14]. It is recognised that chronic ACL insufficiency leads to repeated episodes of instability over a long period of time, and subsequently to new associated lesions and osteoarthrosis.

Many surgical techniques with different types of implant have been described, the most recently used being synthetic materials and allografts $[1,4,10,14,17,30]$.

This study presents our experience of fresh-frozen patellar tendon allografts (bonepatellar tendon-bone) in patients who require either an ACL substitution or reinforcement.

\section{MATERIALS AND METHODS}

The first 30 patients undergoing operations on the ACL Between 1988 and 1991 were included in this prospective study. All were informed of the origin of the graft and, after informed consent was obtained, laboratory tests were carried out as required by current Spanish legislation.

Seventeen patients were male and 13 female with a mean age at the time of injury of 24 years (range 16 to 32 years). Twenty-six had a chronic ACL lesion, and only 4 presented with an acute injury.

All followed a strict protocol with preoperative evaluation and a monthly postoperative review during the first 6 months, at 6 and 12 months, and then yearly. The mean time of follow up was 35 months (range 18 to 54 months).

Twenty-five patients had a sports injury, 12 in soccer, 7 skiing, 2 at basketball, 2 in gymnastics, 1 in athletics, and 1 during judo. In 5 the ACL lesion occurred during their profession or recreation.

Physical examination was carried out by the same doctor in every patient. The diagnosis was based on the anterior drawer test in neutral, external and internal rotation (graded from 1 to 3), Lachman's test evaluating the firmness of the endpoint, and the pivot shift and jerk tests for rotatory instability. Weight-bearing radiographs were taken and a radiographic active Lachman's test was carried out. In the last 10 patients, magnetic resonance imaging was also undertaken.

In 20 patients arthroscopy was performed 12 to 24 months after the operation to obtain arthroscopic assessments and biopsies of the reconstructed ligament.

\section{Operative technique}

The patellar tendon allograft (bone-patellar tendon-bone) was stored in a freezer at $-90^{\circ} \mathrm{C}$, changing to a $-40^{\circ} \mathrm{C}$ on the day before operation. The tendinous part of the graft 
was $1 \mathrm{~cm}$ wide. Immediately before use a stainless steel wire suture was inserted into both ends of the graft and the 2 bone plugs shaped with a small oscillating saw (Fig. 1). Arthroscopy was performed in every case to evaluate the condition of the graft and to treat any associated meniscal or cartilaginous lesions. The graft was implanted by arthroscopy alone in 10 patients, and in the remaining 20 a mini-arthrotomy was performed. The isometric points of insertion of the original ligament were looked for and the remaining fibres used to reinforce and help revascularisation of the allograft. Fixation was obtained by tying the wire suture over a screw and washer in the femur and tibia, always leaving the bone plugs within the tunnels (Fig. 2). In the last 10 patients the proximal bone plug was cut into a conical shape allowing bone-to-bone wedge fixation so that the proximal screw was unnecessary.

Five patients had important dynamic rotatory instability and in these an extra-articular Lemaire reinforcement [12] was performed.

\section{Criteria for evaluation}

We used objective tests and the patient's own subjective assessment, including their overall satisfaction and their ability to return to sports.

We prefer the Arpege de Dejour system which evaluates stability, pain, resistance to fatigue and mobility, using grades 1 to 9. There is also a sports evaluation which includes sports with trauma and torsion of the knee such as soccer, sports with torsion only as in skiing, and those which have neither torsion or trauma like swimming or cycling. The level to which the sport is performed is also evaluated according to the CLAS system - Competition, Loisir (recreation), Active, Sedentary. The final results were classified as:

Excellent: perfect subjective stability, no pain, full movement, same sports level as before, very satisfied.

Good: perfect subjective stability, mild pain on exertion, movement $5^{\circ}$ to $130^{\circ}$, change in level of sport, satisfied.

Fair: apprehension, pain and swelling after exertion, movement $5^{\circ}$ to $120^{\circ}$, change of sport, disappointed.

Poor: accidents due to instability, pain and swelling after daily activity, movement $5^{\circ}$ to $120^{\circ}$, sport with weightbearing not possible, unhappy.

\section{Postoperative care and rehabilitation}

Antibiotics were given routinely with Cefalozin $1 \mathrm{~g} 8$ hourly intravenously for the first week and Cefradoxyl 8 hourly by mouth for the next 2 weeks.

A long-leg plaster cast was applied with $20^{\circ}$ of flexion for 7 days. After the cast was removed, active exercises were begun and a hinged functional brace preventing hyperextension worn for 3 months. Rehabilitation was carried out for 2 months after operation by a physiotherapist in a special centre and included active and passive exercises, electrical muscle stimulation and progressive weight-bearing. Walking without crutches was then allowed. 
After 6 months swimming, cycling and jogging were permitted, avoiding hyperextension. After one year any kind of sport was undertaken provided there was no pain or restriction of movement.

\section{RESULTS}

Subjective evaluation showed excellent results in $33 \%$, good in $52 \%$, fair in $11 \%$ and poor in $4 \%$, with an overall satisfactory result in $85 \%$. Four of the 6 patients who competed in high level sport were able return to this, and 2 returned to the same sport but at a lower level. Fourteen had taken part in recreational sport with occasional regional competitions. All returned to the same level as before. Nine out of the 10 patients who had taken part in sport occasionally were able to continue normally after their operation. Only one did not return to physical activity and now leads a sedentary life.

The objective evaluation of the preoperative condition and the postoperative results is shown in Table 1.

Between the first and second years after operation, 20 patients had one of the screws removed because of local discomfort and at the same time an arthroscopy was performed. The ACL allograft appeared to be covered with normal, well vascularised synovium which was hypervascularised at the ends compared to the middle part of the graft. Most of the graft's bundles were well orientated and were in good tension. Histologically, there were viable fibroblasts and blood vessels interspersed between well organised bundles of collagen. The overlying synovium did not show any evidence of inflammation (Fig. 3).

There were no cases with infection, adhesions or rejection. In 3, manipulation of the knee under anaesthesia was needed.

\section{DISCUSSION}

Soft tissue allografts are an attractive alternative treatment for ligamentous lesions in the knee and other joints, provided they are available and their sterilisation and preservation can be assured. Disease transmission must be avoided, and remodelling anticipated without loss of the ligament's mechanical properties. Our centre is a reference institution for all types of transplantation in Spain, so we obtain our own bone and soft tissue grafts under strict sterile conditions. They are stored until cultures and laboratory tests are negative $[4,5]$.

Freezing, and to a lesser extent freeze-drying, of fresh sterile allografts does not alter the mechanical properties of the implant $[6,8,10]$, whereas irradiation and gamma irradiation decrease the graft's strength, and sterilisation with ethylene oxide produces acute and chronic synovial reaction $[5,9,11]$. In our patients, there has been no clinical evidence showing any kind of immunological reaction. Fresh-freezing at $-90^{\circ} \mathrm{C}$ and liquid nitrogen at $-180^{\circ} \mathrm{C}$ both markedly diminish cellular immunogenicity. The reported risk of acquiring the immunodeficiency syndrome (AIDS) with the use of 
grafts is less than $1: 1,000,000$, and after freezing this is reduced to $1: 8,000,000$ [17]. Nevertheless, it is important that both the donor and host are carefully selected.

Studies reported by different authors confirm that the bone-patellar tendon-bone graft has good mechanical properties and is the preferred method of treating ACL lesions [30]. Its firm fixation in a bony tunnel enables better tension to be achieved, and this allows as early rehabilitation as any type of synthetic implant [21].

Satisfactory results have been reported with autogenous grafts and allografts using the patellar tendon alone or with natural or synthetic reinforcement, either intra- or extraarticular $[4,13,16,18,22,24,29]$. There are very few experimental studies [23, 26, 27 , $28]$, and even fewer clinical studies $[15,25]$ that could determine whether there is any difference in the mid and long term results between autografts or allografts. We have performed an experimental study in lambs and concluded that one year after operation there were no significant differences in mechanical properties, macroscopical and microscopical appearances, or the final clinical outcome between the two groups [20]. Our findings from arthroscopy 18 months after operation in the present study indicated that the macroscopic appearance of the implant was similar to that of a normal ligament. After one year, there was slight decrease in vascularisation of the middle part of the graft, but the tension was good. These findings are supported by other authors [2].

Our results of fresh-frozen patellar tendon allografts are satisfactory when compared with data reported from other techniques and implants, particularly as $87 \%$ of our patients had chronic ACL lesions which have a worse outcome than acute injuries [17]. The patients were assessed from a functional point of view which is important since the aim of the procedure is to enable a return to sports at the same level as before injury. Success is based on the principles which apply to all ACL reconstruction with autografts namely the correct size and width of the implant, isometric positioning and stable fixation with bone plugs allowing early mobilisation.

\section{REFERENCES}

1. Amendola A, Fowler P (1992) Allograft ACL reconstruction in a sheep model: the effect of synthetic augmentation. Am J Sports Med 20: 336-346

2. Amiel D, Kleiner JB, Roux RD, Harwood FL, Akeson WH (1986) The phenomenon of ligamentization: anterior cruciate ligament reconstruction with autogenous patellar tendon. J Orthop Res 4: 162-172

3. Amillo S, Cara JA, Valentí JR (1990) Banco de huesos del sistema musculoesquelético: aplicaciones clínicas. Rev Med Univ Nav 34: 227-234

4. Arnoczky SP, Warren RF, Ashlock M (1986) Replacement of anterior cruciate ligament using a patellar tendon allograft. J Bone Joint Surg [Am] 68: 376-385

5. Butler D (1991) Irradiation of 2 Mrad or less is safe for sterilizing allograft ligaments; but 3Mrad, freezing weaken tissues. Am J Sports Med 19: 7-11

6. Curtis R, De Lee J, Drez D (1985) Reconstruction of the anterior cruciate ligament with freeze dried fascia latta allografts in dogs: a preliminary report. Am J Sports Med 13: 408-414

7. Dejour H, Walch G, Neyret P, Adeline P (1988) Résultats des laxités chroniques antérieures opérées. Rev Chir Orthop 74: 622-636 
8. Drez D, DeLee J, Holden J, Arnoczky S, Noyes F, Roberts T (1991) Anterior cruciate ligament reconstruction using bone-patellar tendon-bone allografts: a biological and biomechanical evaluation in goats. Am J Sports Med 19: 256-263

9. Gibbons MJ, Butler DL, Grood ES, Bylski-Austrow DI, Levy MS, Noyes FR (1991) Effects of gamma irradiation on the initial mechanical and material properties of goat bone-patellar tendon-bone allografts. J Orthop Res 9: 209-218

10. Indelicato P, Bittar E, Prevot T, Woods G, Branch TH, Huegel M (1990) Clinical comparison of freeze-dried and fresh frozen patellar tendon allografts for ACL reconstruction of the knee. Am J Sports Med 18: 335 -342

11. Jackson DW, Windler G, Simon T (1990) Intraarticular reaction associated with the use of freeze-dried, ethylene oxide-sterilized bone-patellar tendon-bone allografts in the reconstruction of the anterior cruciate ligament. Am J Sports Med 18: 1-10

12. Lemaire M, Combelles F (1980) Technique actuelle de plastie ligamentaire pour rupture ancienne du ligament croisé antérieur. Rev Chir Orthop 66: 523-525

13. Levitt RL, Malinin T (1991) Allograft reconstruction of the anterior cruciate ligament a six-year experience with 300 allografts. Arthroscop 7: 318-319

14. McDaniel WR Jr, Dameron TB Jr (1980) Untreated ruptures of the anterior cruciate ligament: a follow up study. J Bone Joint Surg [Am] 62: 696-705

15. Nikolaou PK, Seaber AV, Glisson RR, Ribbeck BM, Bassett FH (1986) Anterior cruciate ligament allograft transplantation: long term function, histology, revascularization and operative technique. Am J Sports Med 14: 348 - 360

16. Noyes F, Barber S (1991) The effect of an extra-articular procedure on allograft reconstructions for chronic ruptures of the anterior cruciate ligament. J Bone Joint Surg [Am] 73: 882-892

17. Noyes F, Barber S, Mangine R (1990) Bone-patellar-bone and fascia lata allografts for reconstruction of the anterior cruciate ligament. J Bone Joint Surg [Am] 72: 1125-1136

18. Noyes FR, Barber S (1992) The effect of a ligament augmentation device on allograft reconstructions for chronic ruptures of the anterior cruciate ligament. J Bone Joint Surg [Am] 74: 960-973

19. Roberts TS, Drez D Jr, McCarthy W, Paine R (1991) Anterior cruciate ligament reconstruction using freeze dried, ethylene oxide-sterilized, bone-patellar tendon-bone allografts: two year results in thirty six patients. Am J Sports Med 19: $35-41$

20. Sala D (1992) Reconstrucción del ligamento cruzado anterior de la rodilla con tendón rotuliano autólogo y homólogo crioconservado en fresco. Estudio experimental en ovejas. Tesis Doctoral, University of Navarra, Pamplona, Spain

21. Sanchis V, Gomar F (1993) Sustitución del ligamento cruzado anterior mediante aloinjertos tendinosos criopreservados. I: Comportamiento biológico del implante a nivel intra-articular. Estudio experimental. Rev Ortop Traum 37 IB: 87-97

22. Shino K, Inoue M, Horibe S, Nagano J, Ono K (1988) Maturation of allograft tendons transplanted into the knee. An arthroscopic and histologic study. J Bone Joint Surg [Br] 70: 556-560

23. Shino K, Kawasaki T, Hirose H, Gotoh I, Inoue M, Ono K (1984) Replacement of anterior cruciate ligament by an allogenic tendon graft: an experimental study in the dog. J Bone Joint Surg [Br] 66: 672-681 
24. Shino K, Kimura T, Hirose H, Inoue M, Ono K (1986) Reconstruction of the anterior cruciate ligament by allogenic tendon graft: an operation for chronic ligamentous insufficiency. J Bone Joint Surg [Br] 68: 739-746

25. Shino K, Nakata K, Inoue M, Horibe S, Hamada M, Nakamura N, Toritsuka Y (1992) Quantitative evaluation following arthroscopic ACL reconstruction: autograft vs allograft. In: Book of abstracts of the first world congress of sports trauma, Spain

26. Thorson E, Rodrigo J, Vasseur P, Sharkey N, Heitter D (1989) Replacement of ACL: a comparison of autografts and allografts in dogs. Acta Orthop Scand 60: 555-560

27. Thorson E, Rodrigo J, Vasseur P, Sharkey N, Heitter D (1987) Comparison of frozen allograft versus fresh autologous anterior cruciate ligament replacement in the dog. Trans Orthop Res Soc 12: 65-70

28. Vasseur PB, Rodrigo UJ, Stevenson S, Clark G, Shonkey N (1987) Replacement of the anterior cruciate ligament with a bone-ligament-bone anterior cruciate ligament allograft in dogs. Clin Orthop 219: 268-277

29. Wainer RA (1988) Arthroscopic reconstruction of the ACL using allograft tendon. Arthroscopy 4: 199-205

30. Woo S, Adams D (1990) The tensile properties of human anterior cruciate ligament (ACL) and ACL graft tissues. In: Daniel D, Akeson W, O'Connor J (eds) Knee ligaments. Structure, function, injury and repair. Raven Press, New York 


\begin{tabular}{|c|c|c|c|c|c|c|c|c|c|c|}
\hline & & & e 1. $\mathrm{P}$ & operati & and $\mathrm{pc}$ & pperativ & clinical & valuat & & \\
\hline & & & pera & & & & & Postol & ative & \\
\hline & Lach & NADt & DtI & $\mathrm{DtE}$ & RI & Lach & NADt & DtI & DIE & RI \\
\hline 1 & +++ & + & + & ++ & ++ & - & - & - & - & - \\
\hline 2 & +++ & ++ & + & + & + & + & + & + & + & + \\
\hline 3 & + & ++ & ++ & ++ & ++ & + & - & - & - & - \\
\hline 4 & + & ++ & + & ++ & + & + & + & - & + & - \\
\hline 5 & ++ & ++ & + & ++ & ++ & + & + & + & + & + \\
\hline 6 & + & ++ & + & ++ & ++ & - & - & - & - & - \\
\hline 7 & ++ & + & + & + & + & - & - & + & - & - \\
\hline 8 & ++ & ++ & ++ & ++ & ++ & - & - & - & - & - \\
\hline 9 & ++ & ++ & ++ & + & + & - & - & - & - & - \\
\hline 10 & ++ & ++ & ++ & +++ & ++ & - & - & - & + & - \\
\hline 11 & ++ & + & + & + & + & + & + & + & + & - \\
\hline 12 & + & ++ & ++ & + & +++ & + & + & + & + & - \\
\hline 13 & + & + & + & + & ++ & + & + & + & + & + \\
\hline 14 & ++ & + & + & + & + & + & + & + & + & + \\
\hline 15 & ++ & + & + & + & ++ & - & - & - & - & - \\
\hline 16 & + & ++ & + & ++ & +++ & - & - & - & - & - \\
\hline 17 & ++ & + & ++ & + & ++ & - & + & + & + & - \\
\hline 18 & + & ++ & ++ & ++ & +++ & - & - & - & - & - \\
\hline 19 & + & ++ & ++ & + & ++ & + & + & - & + & - \\
\hline 20 & ++ & ++ & + & +++ & + & + & + & + & + & - \\
\hline 21 & + & +++ & ++ & +++ & ++ & + & - & - & + & + \\
\hline 22 & ++ & + & + & + & + & - & - & - & - & - \\
\hline 23 & ++ & + & + & ++ & ++ & - & - & + & + & - \\
\hline 24 & + & ++ & ++ & ++ & ++ & - & - & - & - & - \\
\hline 25 & ++ & ++ & + & +++ & +++ & - & - & - & - & - \\
\hline 26 & + & + & ++ & ++ & ++ & - & + & - & + & - \\
\hline 27 & ++ & + & + & + & + & - & - & - & - & - \\
\hline 28 & ++ & ++ & ++ & + & +++ & - & - & - & - & - \\
\hline 29 & ++ & ++ & + & + & ++ & - & - & - & - & - \\
\hline 30 & ++ & ++ & ++ & ++ & ++ & - & - & - & - & - \\
\hline $\begin{array}{l}\text { Graduat } \\
\text { Lach: L } \\
\text { NADt: } \\
\text { DtI: Dr } \\
\text { DtE: Dr } \\
\text { RI: Rot }\end{array}$ & $\begin{array}{l}\text { n from } \\
\text { chman's } \\
\text { nterior } \\
\text { ver test } \\
\text { wer tes } \\
\text { ory inst }\end{array}$ & $\begin{array}{l}\text { - to +++ } \\
\text { est } \\
\text { cawer te } \\
\text { n interna } \\
\text { n extern } \\
\text { bility }\end{array}$ & $\begin{array}{l}\text { in neu } \\
\text { otatio } \\
\text { rotati }\end{array}$ & posit & & & & & & \\
\hline
\end{tabular}




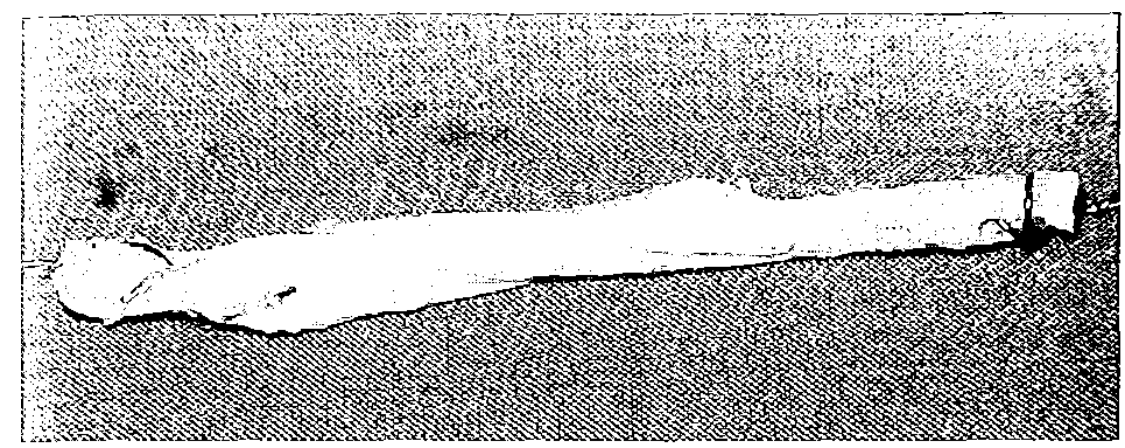

Figure 1. A prepared allograft, ready for transplantation, with a stainless steel wire though the bone plugs at each end
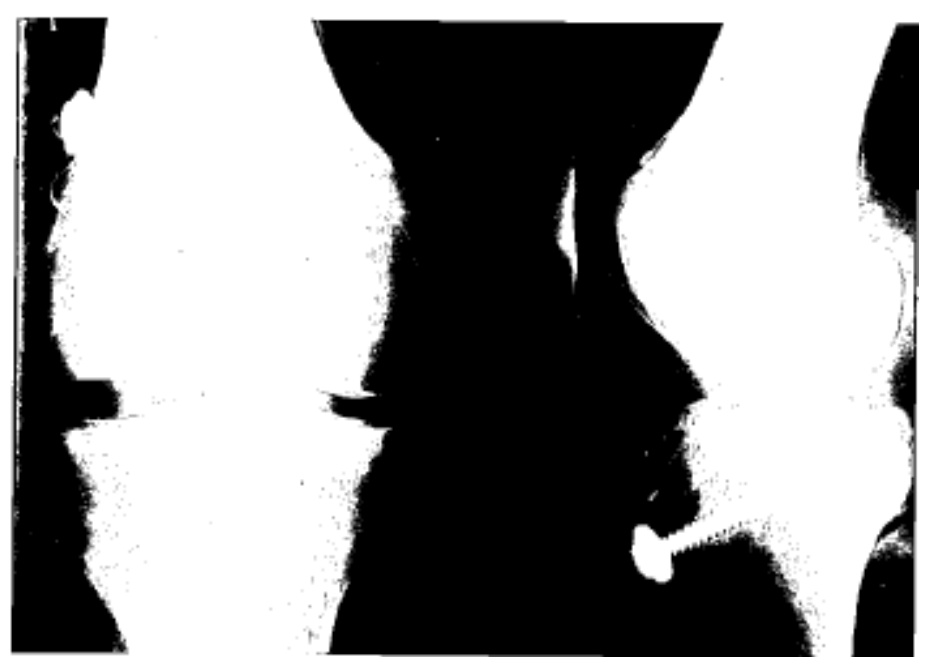

Figure 2. Radiographs after operation showing the fixation points of the graft with the metal images as landmarks

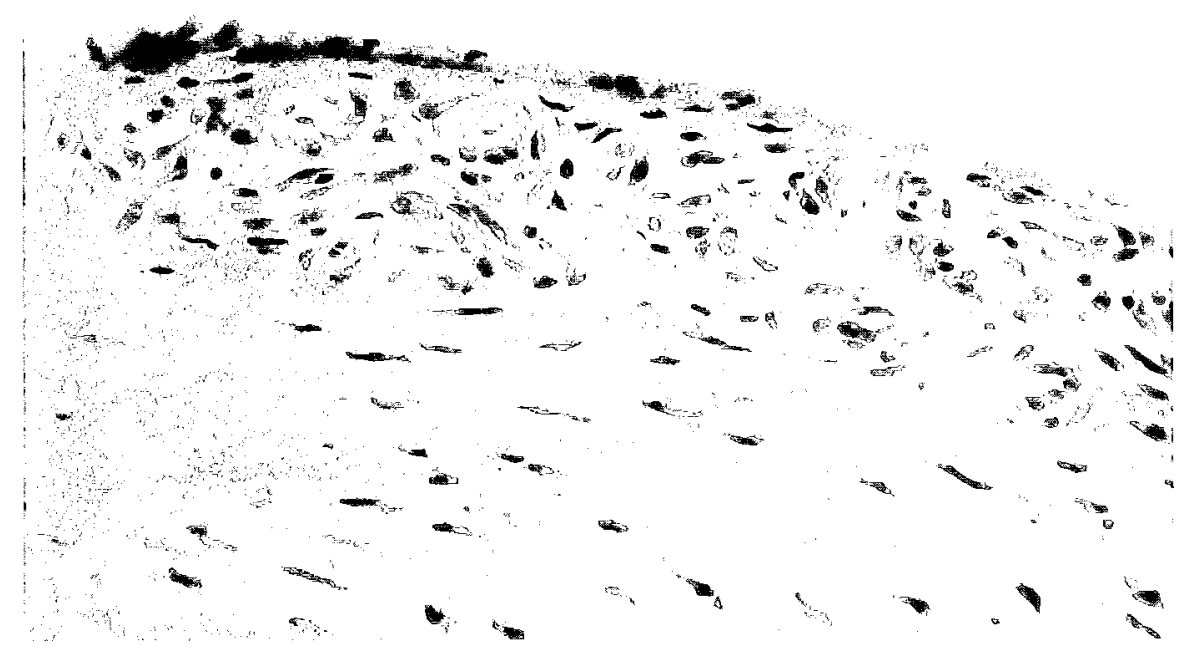

Figure 3. Biopsy taken at arthroscopy 14 months after implantation of the graft. Fibroblasts and collagen are orientated longitudinally. The synovial covering shows no evidence of inflammation and superficial vessels are present 